The Economic Impact of Venture Capital

Astrid Romain

Bruno van Pottelsberghe de la Potterie

IIR Working Paper WP\#03-20

September 2003

Institute of Innovation Research

Hitotsubashi University

Tokyo, Japan

http://www.iir.hit-u.ac.jp 


\title{
The Economic Impact of Venture Capital
}

\author{
Astrid Romain
}

Bruno van Pottelsberghe de la Potterie

September 2003

WP\#03-20 


\title{
THE ECONOMIC IMPACT OF VENTURE CAPITAL
}

\author{
Astrid Romain ${ }^{\nabla}$ and Bruno van Pottelsberghe de la Potterie ${ }^{\alpha}$
}

September 2003

\begin{abstract}
The objective of this paper is to perform a first evaluation of the macroeconomic impact of venture capital (VC). The main assumption is that VC can be considered as being similar to business R\&D performed by large firms. It can therefore contribute to economic growth through two main channels. The first one is innovation, characterized by the introduction of new products, processes or services on the market that directly contribute to improve economic performances. The second one is the development of an absorptive capability. These hypotheses are tested quantitatively with a production function model. The estimates are run over a panel data set of 16 OECD countries from 1990 to 1998. The results show that the accumulation of $\mathrm{VC}$ is a significant factor contributing directly to Multi-Factor Productivity (MFP) growth. The social rate of return to VC is twice as high as the social rate of return to business or public R\&D. VC has also an indirect impact on MFP in the sense that it improves the output elasticity of R\&D. An increased VC intensity makes it easier to absorb the knowledge generated by the universities and firms, and therefore improves aggregate economic performance.
\end{abstract}

Keywords: Venture Capital, Innovation, Productivity Growth, Absorptive Capability

JEL: M13, G24, D24

\section{Acknowledgment :}

We would like to thank Ant Bozkaya (ULB, DULBEA and CEB), Lydia Greunz (ULB, DULBEA), Pierre Mohnen (MERIT) and Reinhilde Veugelers (KUL) for their useful comments. The participants to academic seminars organized at KUL in November 2002, at MERIT in January 2003 and at the Institute of Innovation Research of the Hitotsubashi University in July 2003 also provided insightful suggestions. Astrid Romain had a research grant provided by the Région de Bruxelles-Capitale. The final version of this paper was performed when Bruno van Pottelsberghe was Visiting Professor at the Institute of Innovation Research (IIR), Hitotsubashi University, Tokyo, July-December 2003.

\footnotetext{
${ }^{\nabla}$ Solvay Business School, Universite Libre de Bruxelles (ULB), CP 140, 50 av. F.D. Roosevelt, B-1050, Brussels, BELGIUM. E-mail: astrid.romain@ulb.ac.be.

${ }^{\alpha}$ Solvay Business School, Universite Libre de bruxelles (ULB), Solvay SA Chair of Innovation, CP 14501, Centre Emile Bernheim, av. F.D. Roosevelt 21, B-1050 Brussels, BELGIUM. Tel: +32-2-650.48.99, Fax: +32-2-650.48.99, E-mail: bruno.vanpottelsberghe@ulb.ac.be.
} 


\section{Introduction}

Venture capitalists intervene as an intermediary in financial markets, providing capital to small firms, with high growth potential. Venture funded firms are generally very small and young, often called innovative start-up, and are plagued with very high levels of uncertainty and an important information asymmetry between investors and entrepreneurs. The venture capitalists provide financial support, as equity to support fast growth, and non-financial support as guidance and expertise. They may sit on boards of directors and they may perform key corporate functions for the venture-backed companies or provide valuable governance and advisory support.

Despite the crucial importance of venture capital (VC) for high-tech start-ups, its role in the economy has not been really investigated so far. Some papers attempt to evaluate the impact of VC on firms' performances. There still remain important fields of investigation, especially regarding the aggregate economic impact of VC. Baumol (2002), for instance, argues that entrepreneurial activity may account for a significant part of the "unexplained" residual in the traditional Cobb-Douglas production function. The objective of this paper is precisely to evaluate Baumol's conjecture: whether and to what extent VC contributes to economic growth. We set the hypothesis that $\mathrm{VC}$ can be considered as being similar to experimental development activities performed in large firms. In this respect, the contribution of VC would take place through two main channels: innovation (i.e., the introduction of new products and processes on the market), and absorptive capability (i.e., the development of know-how and skills that induce an effective use of existing knowledge to improve the production system).

The paper is structured as follows: the next section focuses on the existing literature related to our field of investigation. The empirical model as well as the data and the econometric results are presented in the third section. The final section concludes.

\section{Existing investigations}

There has been no attempt so far, to the best of our knowledge, to formally evaluate the aggregate impact of $\mathrm{VC}$ on economic growth. However a lot of factual evidence, especially for the US economy, has been published in the existing literature. According to a study carried out by DRI-WEFA on US VC-financed companies over the period 1970-2000, "venture capitalbacked companies had approximately twice the sales, paid almost three times the federal taxes, generated almost twice the exports, and invested almost three times as much in R\&D as the average non-venture capital-backed public company, per each $\$ 1,000$ of assets" (NVCA, 2002). This study also shows that VC fosters local and regional economic growth in the USA. The European Venture Capital Association (EVCA, 1996 and 2001) argues that venture-backed companies stimulate the economy through the creation of jobs, their exceptional growth rate, their heavy investments and their international expansion. VC is considered as a factor decreasing substantially the time necessary to introduce an innovation on the market. The report of the EVCA (2001) shows that venture-backed companies increasingly benefit from general investments. Venture-backed companies' commitment in R\&D expands Europe's technical expertise and resources, and strengthens its competitive position in the world markets. International competitiveness is also enhanced by significant growth in export sales.

A few empirical investigations on the impact of $\mathrm{VC}$ on firm's performance have been performed at the micro level. Hellmann and Puri (2000) implemented a survey of 149 recently formed firms in the Silicon Valley (USA). Their empirical results suggest that VC stimulates innovative activities of firms. A start-up financed by a venture capitalist needs less time to bring 
a product to the market. They also show that firms pursuing an "innovator strategy" potentially have better and quicker access to VC funds. Nevertheless, these results should be interpreted with caution since the authors face a problem of causality and geographical concentration of firms. Indeed, as far as the causality problem is concerned, it is possible that the more a firm is innovative, the more it applies for VC. In this sense, it is not the VC that would stimulate firms to be more innovative. The validity of these conclusions is also limited by their sample, which includes only Silicon Valley start-ups. For the authors VC can have an impact on the technological trajectory of a start-up company, and in particular on its product market position.

Hellmann and Puri (2002) examine the additional role played by venture capitalists compared to traditional financial intermediation. The authors focus on the development of 170 young hightechnology firms in Silicon Valley. Venture capitalists intervene in a huge range of activities that are important for the professionalization and development of a start-up company (the formulation of human resource policies, the adoption of stock option plans, etc.). Engel (2002) performed another microeconomic evaluation of the impact of VC on 1,000 German start-ups. The surviving German venture-backed companies seem to achieve significant higher growth rates due to financial involvement and services provided by venture capitalists. The author also shows that the impact of VC on new firms' growth does not differ between high-tech and lowtech industries.

Kortum and Lerner (2000) are amongst the few authors who perform an aggregate evaluation of the relation between VC and Innovation. The authors examine the influence of VC on patented inventions in the US from 1965 to 1992 using 20 industries and 530 venture-backed and nonventure-backed firms. They find that VC activity significantly increases the propensity to patent. Moreover, VC seems to be more efficient in stimulating patenting compared to traditional corporate $\mathrm{R} \& \mathrm{D}$. The impact of venture funding on patent applications is several times higher than the one of corporate R\&D. They also show that while from 1983 to 1992 the ratio of VC to R\&D was on average smaller than $3 \%$, VC may have accounted for $8 \%$ of industrial innovations during the same period. Gompers and Lerner (2001) criticise this analysis. For them, the impact of $\mathrm{VC}$ on innovation and economic growth is a very important question. But a simple model of the relationship between $\mathrm{VC}, \mathrm{R} \& \mathrm{D}$ and innovation is likely to give misleading estimates because both venture funding and patenting could be positively related to a third unobserved factor - the arrival of technological opportunities.

This issue of causality is also analysed by Engel and Keilbach (2002) who compare 142 venture-funded firms with more than 20,000 non venture-funded firms in Germany. Their analysis provides evidence on several levels. Firms with an innovative performance, proxied by a patent performance indicator, are able to benefit from venture funds with a higher probability. Once a start-up is venture funded it shows higher employment growth rates but no significant difference in innovative output.

Finally, it is worth mentioning the aggregate analysis of Audretsch and Keilbach (2002). They evaluate the impact of entrepreneurship capital on the economic performances of German regions. Their results indicate that entrepreneurship capital (proxied by the number of start-ups in a region, relative to its population) is a significant and important factor shaping output and productivity.

In a nutshell, there is some evidence that $\mathrm{VC}$ and entrepreneurial activity fosters innovative, patenting and growth performances, at least in the USA and Germany. Nevertheless, there is no formal evaluation of the impact of $\mathrm{VC}$ on aggregate economic growth, and very few investigations in other industrialised countries. In what follows we attempt to evaluate the macroeconomic impact of VC in 16 OECD countries, over the period 1990-1998. 


\section{Empirical implementation}

Our basic hypothesis is that VC investment is somewhat similar in its nature to experimental development that is mainly performed by large firms - the " $D$ " of R\&D. According to the definition of the OECD Frascati manual (1993), Research and experimental development $(R \& D)$ comprise creative work undertaken on a systematic basis in order to increase the stock of knowledge, including knowledge of man, culture and society, and the use of this stock of knowledge to devise new applications. More precisely, this definition can be divided into 3 types of R\&D: basic research, applied research, and development. Basic research is experimental or theoretical work undertaken primarily to acquire new knowledge of the underlying foundations of phenomena and observable facts, without any particular application or use in view. Applied research is also original investigation undertaken in order to acquire new knowledge. It is, however, directed primarily towards a specific practical aim or objective. And experimental development is systematic work, drawing on existing knowledge gained from research and practical experience, that is directed to producing new materials, products and devices; to installing new processes, systems and services; or to improving substantially those already produced or installed. This third definition of $\mathrm{R} \& \mathrm{D}$ is quite similar to the activities that are implemented in small innovative companies. Since they are often financed by venture funds, it seems legitimate to assume that VC can be considered as a determinant of economic growth because it directly contributes transforming inventions into new products and processes.

The second effect of VC would be rather indirect. Venture funded activities can be assimilated to intensive learning processes. We therefore assume that it allows developing a rapid and effective absorptive capability of outside knowledge.

The contribution of $\mathrm{VC}$ to aggregate productivity growth is therefore evaluated through two main mechanisms. The first mechanism would be the direct contribution of $\mathrm{VC}$ to productivity growth induced by the creation of new products and processes. The second mechanism would act through the development of an absorptive capability.

In order to test the assumption that $\mathrm{VC}$ is a determinant of economic growth, we use $\mathrm{VC}$ as an additional source of knowledge in a traditional knowledge production function. Various sources of technical change are therefore taken into account including business and public R\&D capital stocks, and the VC stock. Business-cycle effects that strongly influence productivity in the short run are also included as 'control' variables. The model on which the estimated equation is based is a traditional Cobb-Douglas production function.

$$
M F P_{i t}=\exp \left\lfloor\phi_{i}+\varphi_{t}+\mu_{i t}\right\rfloor \cdot S V C_{i t-1}^{\beta_{s v c}} \cdot S B R D_{i t-1}^{\beta_{s b r d}} \cdot S P R D_{i t-2}^{\beta_{s p r d}} \cdot U_{i t}^{\sigma_{U}} \cdot G^{\sigma_{G}}
$$

The variables (for country $i$ and time $t$ ) are defined as follows:

$M F P$ is an index of total factor productivity $(M F P)$ and has been computed in the usual way (OECD, 2001), as the ratio of the domestic product of industry on the weighted sum of the quantity of labour and fixed capital stock, the weights being the annual labour cost share and the capital cost share respectively (under assumptions of perfect competition and constant return to scale). (Source: OECD National Accounts database).

$S V C$ is the stock of domestic venture capital. It has been computed using the perpetual inventory method from venture expenditures, in constant 1990 GDP prices and US PPPs (see appendix 2). The venture expenditures include only seed, start-up and early stage capital and doesn't include replacement capital and buyout. Since VC is a highly risky investment and concerns more development than basic research, we rely on a high depreciation rate to compute the stock of $\mathrm{VC}$. The annual depreciation rate is $30 \%{ }^{1}$ (Sources: EVCA and OECD). 
$S B R D$ is the domestic business R\&D capital stock. It has been computed using the perpetual inventory method from total intramural business R\&D expenditures, in constant 1990 GDP prices and US PPPs (see appendix 2). The depreciation rate is $15 \%$. Sensitivity analysis show that the results of the regressions do not change significantly with the chosen depreciation rate (Guellec and van Pottelsberghe, 2001 and 2003). (Source: OECD Main Science and Technology Indicators).

$S P R D$ is the public $\mathrm{R} \& \mathrm{D}$ capital stock (see appendix 2), which comprises $\mathrm{R} \& \mathrm{D}$ expenditures performed in the higher education sector and in the government sector (public laboratories). The depreciation rate is $15 \%$. Again, sensitivity analysis show that the results of the regressions do not change significantly with the chosen depreciation rate (Guellec and van Pottelsberghe, 2001 and 2003). Since these R\&D activities are not performed by the business sectors, we expect a longer delay before they affect business productivity and therefore include them in the model with a two-year lag.

A range of control variables is included in all the regressions.

$U \quad$ is intended to capture the business cycle effect: it is equal to 1 minus the unemployment rate. This should be a better proxy than the usually applied rate of utilisation of capital, which applies to manufacturing industries only (which account for about $20 \%$ of GDP in OECD countries). In the context of this study, it is also better than the output gap, as the calculation of the output gap relies on certain assumptions on MFP growth: by using it, we would be faced with simultaneity problems (if MFP is the same on both sides of the equation) or inconsistency (if two different MFPs are used on the two sides of the equation).

$G \quad$ is a dummy equal to 1 for Germany in 1991, and 0 otherwise; in order to take into account the exogenous shock of the German unification.

$\phi_{i} \quad$ are country dummies which allow country-specific framework conditions that might affect long-term growth.

$\varphi_{t} \quad$ are time dummies which take into account exogenous technical change and exogenous shocks that are common to several countries, such as changes in exchange rates.

The basic equation we estimate is adapted from equation (1). It is a long-term stationary form of the model expressed in logarithm:

$$
L M F P_{i t}=\beta_{s v c} L S V C_{i t-1}+\beta_{s b r d} L S B R D_{i t-1}+\beta_{s p r d} L S P R D_{i t-2}+\sigma_{U} \Delta U_{i t}+\sigma_{G} G+\phi_{i}+\varphi_{t}+\mu_{i t}
$$

where $\Delta$ represents the first logarithmic difference and $L$ the natural logarithm. In this equation, the parameters that are to be estimated are assumed to be constant across countries and over time; they are defined as follows:

$\beta_{s v c} \quad$ The elasticity of $M F P$ with respect to $\mathrm{VC}$.

$\beta_{\text {sbrd }} \quad$ The elasticity of $M F P$ with respect to domestic business R\&D.

$\beta_{\text {sprd }} \quad$ The elasticity of $M F P$ with respect to public R\&D.

$\sigma_{U} \quad$ The elasticity of $M F P$ with respect to the capacity utilisation growth rate.

$\sigma_{G} \quad$ The impact of the German unification on MFP in Germany.

The interpretation of these elasticities must take into account the fact that the explained variable is not GDP but MFP. That means that we capture mainly the spillover effects of R\&D and VC, not the total effect on output growth (which includes also the direct effect on private return). This concerns especially business $\mathrm{R} \& \mathrm{D}$ and $\mathrm{VC}$ as part of the private resources devoted to R\&D and/or financed by VC (labour and capital) are already reflected in the calculation of MFP (they 
are included in the economy's stock of capital and pool of labour). A positive elasticity would signal the existence of spillovers and a risk premium. A further caveat is that the assumptions used for calculating MFP may not hold totally: increasing returns to scale and imperfect competition are often associated with R\&D (e.g. Romer, 1990). If that is the case, the MFP index that we explain might be subject to some measurement errors. ${ }^{2}$

Table I reports descriptive statistics for all the variables and countries over the period of 199098 (or the longest available period). The MFP growth ranges from -0.52 per cent a year in Germany to 3.71 per cent in Ireland. This weak rate for Germany is mainly due to the period analysed that includes the German unification. Most countries, however, are very close to 1 per cent a year. The $M F P$ growth is high for Ireland, as this country has been catching up over this period. Business R\&D (capital stock) growth ranges from 0.79 per cent (United Kingdom) to 7.33 per cent (Finland) and an outstanding performance of 15.49 per cent for Ireland. Most countries are between 4 and 7 per cent. The growth of public R\&D performed was much lower than that of business $R \& D$ over the same time period. It ranges from 1.07 (Canada) to 5.22 per cent (Ireland), with most countries reporting between 3 and 5 per cent.

The major reasons for this lower growth rate in public R\&D are the end of the cold war (reduced defence spending) and strained budgetary conditions in many countries. VC investment is much more volatile, ranging from -3.7 per cent in Australia to 34.5 per cent in Canada with the United States and Finland above 20 per cent. Note that we only have data from 1995 to 1998 for Canada and Australia, which can explain these high values. The descriptive statistics for the VC stock with 30, 45 and 60 per cent of depreciation are in Appendix 1, Table AII. Despite a higher volatility, the average growth rates of VC investment and VC stock have been much higher than the growth rate of business $R \& D$ capital stock, except for a few countries.

The $R \& D$ intensity ( $R \& D$ investment divided by the domestic product of industry) varies between 1.2 per cent and 2.2 per cent for 10 countries. Sweden, Japan, Finland, and the USA are the best performers in terms of relative effort in R\&D. Regarding the VC intensity (VC investment divided by the domestic product of industry) the best performers are not necessarily the countries that have a high R\&D intensity. Japan is the least intensive in VC. Australia, the Netherlands, the United-Kingdom and the United States are around 0.10 per cent and Canada is at the top with 0.20 per cent. In other words, some countries with relatively low effort in research turn out to be very active in terms of $\mathrm{VC}$.

Based on the equation in log-levels (2), our aim is to identify simple, long-term static relationships between $M F P$ and its determinants. Panel co-integration tests are not performed because of the short period considered. These tests have been performed on similar data (MFP, SBRD, SPRD) by van Pottelsberghe and Lichtenberg (2001) for the same sample of countries but for a longer time period. They find that the combination of the time series satisfy the required statistical properties needed for meaningful estimations.

The econometric results are reported in Table II. The variables of business R\&D capital stock and VC stock have been introduced with a one-year lag (or the stock at the beginning of the year), and two years lag for the public R\&D capital stock. Since R\&D performed by universities largely concerns basic research, a longer time lag is justified. Indeed, it takes time until basic $\mathrm{R} \& \mathrm{D}$ affects industrial productivity. ${ }^{3}$

The results for different specifications are reported in order to test the stability of our estimates. The control variable 'business cycle', as proxied by the growth of employment rate, is associated with an expected large and positive parameter. This confirms previous findings that the measure of productivity is substantially affected by the capacity utilization rate.

One can observe that the progressive introduction of the other sources of knowledge significantly improves the overall fit of the model. The estimates suggest that the accumulation 
of VC significantly contributes to total factor productivity growth. The estimated parameters remain stable (columns 5 and 6) after the withdrawal of the control variables and/or time dummies, witnessing the robustness of the estimated parameters.

The most appropriate estimates are displayed in column 3. These results include the three sources of knowledge, the two control variables, and country and time dummies. The elasticities of output with respect to the stocks of $\mathrm{VC}$, business $\mathrm{R} \& \mathrm{D}$ and public R\&D are 1 per cent, 18 per cent, and 9 per cent, respectively. In other words, the output elasticity of business R\&D is twice as high as the output elasticity of public R\&D and nearly 20 times as high as the output elasticity of VC.

As the direct impact of $\mathrm{R} \& \mathrm{D}$ and $\mathrm{VC}$ on output is at least partly accounted for in MFP, this positive coefficients must mainly capture spillovers and possibly a premium (coming in addition to normal remuneration of capital and labour) arising from R\&D and VC. In addition, these estimates are elasticities: relative increase in output due to a relative increase in the stock of knowledge. For instance, a one per cent variation in the business R\&D capital stock would yield a 0.2 per cent variation in output. In order to quantify these estimates in terms of Euro, one must compute the marginal impacts of these sources of knowledge.

Table III shows the marginal impacts, or social rates of return, of the three types of knowledge stocks. They correspond to the elasticities presented in column 3 of Table II. The rates of return are calculated as the elasticities divided by the average intensity of the knowledge stock. For instance, the marginal impact of business $\mathrm{R} \& \mathrm{D}$ is $0.182 /(0.0961)=1.90$. The marginal impacts of public R\&D and VC are respectively 1.78 and 4.46. In other words, an increase of one Euro in business R\&D capital stock would yield an increase of 1.9 Euro in output growth. The rate of return to public R\&D is quite similar. What is striking is the social rate of return to $\mathrm{VC}$, which is more than twice as high as the social rate of return to business $R \& D$. This is probably due to the high risk-premium of $\mathrm{VC}$ and its associated spillover effects on the economy. Indeed, by definition, venture capitalists invest in highly risky projects such as the introduction of highly innovative products and processes on the market. In large firms, development activities also concern more incremental innovations (product and process improvement) that yield lower returns than a successful introduction of a breakthrough innovation.

The second potential effect of VC on economic performances is an indirect one. Since VC activities can be compared to an intensive learning process, it is assumed that it would improve and speed up the absorptive capability of firms. The potential mechanism is similar to the one emphasized by Guellec and van Pottelsberghe $(2001,2003)$ with R\&D outlays. The authors show that the countries with a higher R\&D intensity have a higher impact of their business R\&D capital stock, thanks to an improved absorptive capability of existing knowledge (inside and outside the firm's boundaries).

In order to test this hypothesis of an absorptive capability associated with both R\&D investment and $\mathrm{VC}$, we estimate a model similar to equation (2), but where VC intensity and business R\&D intensity (i.e. the ratio of business R\&D expenses on DPI-Domestic Product of Industry) interact with the various knowledge capital stocks. The results are presented in Table IV.

A country's business R\&D intensity has a positive effect on the elasticity of the business R\&D capital stock as shown in column 1 of Table IV. This finding confirms to some extent the existence of increasing returns to investment in research activities. Increasing returns to scale is the basic assumption of the theory of endogenous technical change (see Romer, 1990). By spending more on $\mathrm{R} \& \mathrm{D}$, firms are able to reap internal economies of scale, to set up networks, to benefit from each other's discoveries. It also denotes an improved ability to absorb the knowledge generated by other firms and/or industries. The intensity of $\mathrm{VC}$ funding has also a positive effect on the elasticity of the business R\&D capital stock (column 2). 
When we introduce simultaneously the product of the business $R \& D$ capital stock with the R\&D intensity the $\mathrm{VC}$ intensity (column 3 ), we observe that the positive impact of business research is much higher in countries were the R\&D intensity and the VC intensity is higher. The elasticity of public research is also higher when the business $R \& D$ intensity is higher. This shows the importance of the business sector being able to seize opportunities raised by public research (column 4). Therefore, part of the effect of public research on productivity is indirect, flowing through the use of its discoveries by the business sector research activities. Stronger links between public and private research, which governments in most OECD countries are trying to build, should enhance this effect. The intensity of VC investment also positively affects the impact of public R\&D (columns 5 and 6). More VC allows absorbing more outside knowledge increasing therefore the innovative performances of firms and the aggregate impact of business and public R\&D activities.

\section{Concluding remarks}

To the best of our knowledge, this paper provides a first attempt to evaluate the economic impact of venture capital. The starting point of our investigation is that venture capital can be considered in several respect to be similar to experimental development performed by large firms. The econometric results confirm our assumption that $\mathrm{VC}$ contributes to growth through two main channels. The first one is the introduction of new products and processes on the market and the second one is the development of an improved absorptive capability of the knowledge generated by private and public research institutions.

The social return to venture capital is much larger than the return to $R \& D$, probably due to a high risk premium and large potential spillovers or knowledge externalities - large firms devote the bulk of their research activities to product or process improvement which is associated with lower risks and lower expected returns. A high venture capital intensity further allows to improve the economic impact of private and public R\&D capital stocks. In other words, venture capital improves the crystallisation of knowledge into new products and processes.

According to our estimates, venture capital must be considered as an additional "link" explaining variations in economic performances. In the line of Audretsch and Keilbach (2002)'s empirical results, we confirm Baumol's conjecture that entrepreneurial activity may account for a significant part of the "unexplained" residual in the traditional production function. These results therefore call for innovative policy instruments that would stimulate the amount of venture capital offered on the market.

\footnotetext{
${ }^{1}$ Sensitivity analyses are shown in Table A2 of Appendix 1 . The results of the regressions do not change significantly with the chosen depreciation rate.

${ }^{2}$ See Guellec and van Pottelsberghe (2003) for a discussion on this issue.

${ }^{3}$ See Guellec and van Pottelsberghe (2001) for a more in depth analysis of the lag structure associated with the R\&D capital stocks. As far as the direct impact of VC on MFP is concerned we start by estimating separately the effect of each variable. The results are reported in Table A1 (in Appendix 1). All variables have the expected signs and are highly significant. Our estimates are based on GLS econometric technique.
} 


\section{References}

Audretsch, D.B. and M. Keilbach, 2002, 'Entrepreneurship capital and economic performance', ZEW Discussion Paper, 02-76, 20p.

Baumol, W.J., 2002, Free market innovation machine: analyzing the growth miracle of capitalism, Princeton University Press.

Engel, D., 2002, 'The impact of venture capital in firm growth: an empirical investigation', ZEW Discussion paper, 02-02, 30p.

Engel, D. and M. Keilbach, 2002, 'Firm level implications of early stage venture capital investment- an empirical investigation', ZEW Discussion paper, 02-82, 21p.

EVCA, 1996, 'The economic impact of venture capital in Europe, in collaboration with Coopers \& Lybrand Corporate Finance', mimeo.

EVCA, 2001, 'Policy Priorities for Private Equity: Fostering Long-Term Economic Growth', EVCA White Paper, mimeo.

Gompers, P. and J. Lerner, 2001, 'The Venture Capital Revolution', Journal of Economic Perspectives, 15 (2), pp 145-168.

Guellec, D. and B. van Pottelsberghe, 2001, 'R\&D and productivity growth : panel data analysis of 16 OECD countries', OECD Economic Studies, 33 (2), pp. 103-126.

Guellec, D. and B. van Pottelsberghe, 2003, 'From R\&D to Productivity Growth: The Sources of knowledge spillovers and their interaction', mimeo.

Hellmann, T. and M. Puri, 2000, 'The Interaction between Product Market and Financing Strategy: The Role of Venture Capital', Review of Financial Studies, 13, pp. 959-84.

Hellmann, T. and M. Puri, 2002, 'Venture Capital and the Professionalization of Startup Firms: Empirical Evidence', Journal of Finance, 57 (1), pp. 169-197.

Kortum, S. and J. Lerner, 2000, 'Assessing the Contribution of Venture Capital to Innovation', RAND Journal of Economics, 31 (4), pp. 674-692.

National Venture Capital Association, 2002, 'DRI-WEFA Study Identifies Venture Capital as a Key Factor Powering U.S. Economic Growth', Press Release, June 26, Washington, DC.

OECD, 1993, FRASCATI MANUAL, Organisation for Economic Co-operation and Development, Paris.

OECD, 2001, 1999, 1997, OECD statistics: Main science and technology indicators, 1, Organisation for Economic Co-operation and Development, Paris.

OECD, 2001, The OECD Productivity Manual, Organisation for Economic Co-operation and Development, Paris.

Romer, P.M., 1990, 'Endogenous Technical Change', Journal of Political Economy, 98, pp. 71102.

Van Pottelsberghe de la Potterie, B. and F. Lichtenberg, 2001, 'Does Foreign Direct Investment Transfer Technology across Borders?', Review of Economics and Statistics, 83 (3). 


\section{Tables}

Table I: Descriptive statistics (\%)

\begin{tabular}{|c|c|c|c|c|c|c|c|}
\hline \multirow[t]{2}{*}{ Country } & \multirow[t]{2}{*}{ Period } & $\begin{array}{c}\text { Business } \\
\text { R\&D capital } \\
\text { stock }\end{array}$ & $\begin{array}{l}\text { Public R\&D } \\
\text { capital stock }\end{array}$ & $\begin{array}{l}\text { Total Factor } \\
\text { Productivity }\end{array}$ & $\begin{array}{c}\mathrm{VC} \\
\text { Investment }\end{array}$ & $\begin{array}{l}\text { Business R\&D } \\
\text { Intensity }\end{array}$ & VC Intensity \\
\hline & & \multicolumn{4}{|c|}{ Yearly average growth rates } & \multicolumn{2}{|c|}{$\%$ Shares } \\
\hline $\mathrm{AU}$ & $1995-98$ & 5.79 & 4.23 & 2.09 & -3.65 & 0.83 & 0.10 \\
\hline $\mathrm{BE}$ & $1990-97$ & 3.57 & 3.34 & 0.78 & 14.51 & 1.41 & 0.06 \\
\hline $\mathrm{CA}$ & $1995-98$ & 4.95 & 1.07 & 0.96 & 34.50 & 1.25 & 0.20 \\
\hline DK & 1990-98 & 7.18 & 4.23 & 1.76 & 14.96 & 1.67 & 0.02 \\
\hline FI & 1990-98 & 7.33 & 4.82 & 3.10 & 24.63 & 2.20 & 0.06 \\
\hline FR & $1990-98$ & 2.80 & 1.81 & 0.58 & 4.95 & 1.92 & 0.06 \\
\hline GE & $1990-98$ & 1.43 & 3.41 & -0.52 & 12.40 & 2.09 & 0.05 \\
\hline IR & $1990-97$ & 15.49 & 5.22 & 3.71 & 1.20 & 1.11 & 0.07 \\
\hline IT & $1990-97$ & 2.46 & 2.41 & 0.94 & 2.44 & 0.75 & 0.03 \\
\hline JP & 1994-98 & 3.55 & 3.72 & 0.11 & 8.46 & 2.26 & 0.02 \\
\hline NL & $1990-98$ & 1.78 & 3.45 & 0.91 & 13.53 & 1.32 & 0.12 \\
\hline NO & $1990-97$ & 3.23 & 3.96 & 1.96 & 16.14 & 1.32 & 0.07 \\
\hline SP & $1990-98$ & 4.07 & 1.13 & 0.75 & 13.91 & 0.56 & 0.03 \\
\hline SW & $1990-97$ & 5.75 & 1.69 & 1.78 & 4.81 & 3.69 & 0.05 \\
\hline UK & $1990-98$ & 0.79 & 1.65 & 0.85 & 5.96 & 1.83 & 0.10 \\
\hline US & $1990-98$ & 2.72 & 1.53 & 1.18 & 21.41 & 2.21 & 0.10 \\
\hline
\end{tabular}

Sources: OECD, MSTI, EVCA and own calculations 
Table II: Multifactor productivity estimation results in log-levels

\begin{tabular}{|c|c|c|c|c|c|c|c|c|}
\hline \multicolumn{9}{|c|}{ Dependent variable Log MFP } \\
\hline Regressions (GLS) & & & 1 & 2 & 3 & 4 & 5 & 6 \\
\hline \multirow[t]{2}{*}{ Log Venture capital stock (t-1) } & $\delta=30 \%$ & $L S V C$ & $0.013^{* * *}$ & $0.012 * * *$ & $0.010 * * *$ & $0.033 * * *$ & $0.007 * *$ & $0.006^{* *}$ \\
\hline & & & $(5.24)$ & $(4.00)$ & $(3.15)$ & (6.19) & $(2.26)$ & (1.99) \\
\hline \multirow{2}{*}{ Log Business R\&D capital stock (t-1) } & & $L S B R D$ & & $0.190 * * *$ & $0.182 * * *$ & & $0.182 * * *$ & $0.197 * * *$ \\
\hline & & & & $(10.68)$ & (9.10) & & (9.53) & $(12.02)$ \\
\hline \multirow[t]{2}{*}{ Log Public R\&D capital stock (t-2) } & & $L S P R D$ & & & $0.092 *$ & & $0.142 * * *$ & $0.162 * * *$ \\
\hline & & & & & (1.83) & & $(5.00)$ & $(5.93)$ \\
\hline \multicolumn{9}{|l|}{ Control variables } \\
\hline \multirow[t]{2}{*}{ Employment rate growth $(\mathrm{t})$} & & & $0.760 * * *$ & $0.562 * * *$ & $0.618^{* * *}$ & $1.56^{* * *}$ & $0.851 * * *$ & \\
\hline & & & $(4.31)$ & (3.53) & (3.71) & (7.49) & $(6.96)$ & \\
\hline \multirow[t]{2}{*}{ German reunification dummy $(\mathrm{t})$} & & & -0.004 & -0.015 & -0.014 & -0.047 & -0.020 & \\
\hline & & & $(-0.08)$ & $(-0.42)$ & $(-0.38)$ & $(-1.30)$ & $(-0.53)$ & \\
\hline Country-specific intercept & & & Yes & Yes & Yes & Yes & Yes & Yes \\
\hline Time dummies & & & Yes & Yes & Yes & No & No & No \\
\hline Adjusted R-squared & & & 0.941 & 0.949 & 0.961 & 0.745 & 0.984 & 0.972 \\
\hline
\end{tabular}

Note: Panel data, 16 OECD countries, $1990-98,125$ observations. ${ }^{\nabla}$ Indicates the parameters that are significant at a $15 \%$ probability threshold, $* 10 \%$ probability threshold, $* * 5 \%$ probability threshold and $* * * 1 \%$ probability threshold. 
Table III: Long-term elasticity of Total Factor Productivity

\begin{tabular}{|c|c|c|c|c|}
\hline & & $\beta$ & Intensité & $\rho$ \\
\hline Venture capital stock & $\delta=30 \%$ & 0.010 & 0.0022 & 4.46 \\
\hline Business R\&D capital stock & & 0.182 & 0.0961 & 1.90 \\
\hline Public R\&D capital stock & & 0.092 & 0.0518 & 1.78 \\
\hline
\end{tabular}

Sources: own calculations, with the parameters presented in Table II, column 3. 
Table IV: Multifactor productivity estimation results in log-levels: VC and R\&D as factors of absorptive capabilities

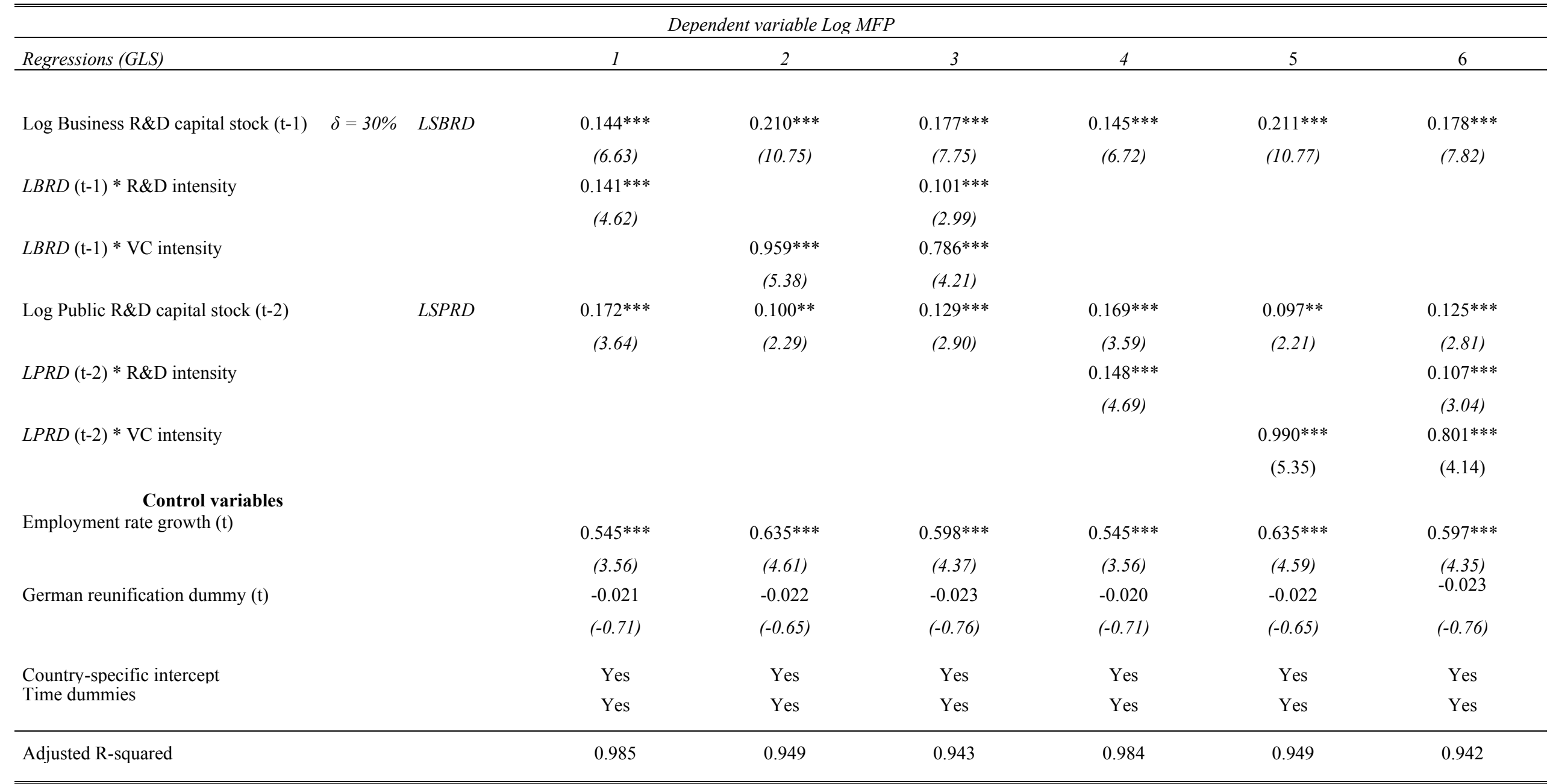

Note: Panel data, 16 countries, $1990-98,125$ observations. ${ }^{\nabla}$ Indicates the parameters that are significant at a $15 \%$ probability threshold, * $10 \%$ probability threshold, $* * 5 \%$ probability threshold and $* * * 1 \%$ probability threshold. 


\section{APPENDIX 1: Other specifications of the models}

\section{Different estimates of the static model}

Table AI: Multifactor productivity estimation results in log-levels

\begin{tabular}{|c|c|c|c|c|c|}
\hline \multicolumn{6}{|c|}{ Dependent variable Log MFP } \\
\hline Regressions (GLS) & & 1 & 2 & 3 & 4 \\
\hline \multirow[t]{2}{*}{ Log Venture capital stock (t-1) } & $L S V C$ & $0.013 * * *$ & & & \\
\hline & & (5.24) & & & \\
\hline \multirow[t]{2}{*}{ Log Business R\&D capital stock (t-1) } & $L S B R D$ & & $0.194 * * *$ & & $0.177 * * *$ \\
\hline & & & $(11.35)$ & & (8.92) \\
\hline \multirow[t]{2}{*}{ Log Public R\&D capital stock (t-2) } & LSPRD & & & $0.333 * * *$ & $0.137 * * *$ \\
\hline & Control variables & & & $(8.40)$ & $(2.94)$ \\
\hline \multirow[t]{2}{*}{ Employment rate growth $(\mathrm{t})$} & & $0.760 * * *$ & $0.471 * * *$ & $0.916 * * *$ & $0.628 * * *$ \\
\hline & & $(4.31)$ & $(3.25)$ & $(5.84)$ & (3.98) \\
\hline \multirow{2}{*}{\multicolumn{2}{|c|}{ German reunification dummy $(\mathrm{t})$}} & -0.004 & -0.018 & -0.005 & -0.017 \\
\hline & & $(-0.08)$ & $(-0.54)$ & $(-0.11)$ & $(-0.46)$ \\
\hline Country-specific intercept & & Yes & Yes & Yes & Yes \\
\hline Time dummies & & Yes & Yes & Yes & Yes \\
\hline Adjusted R-squared & & 0.941 & 0.970 & 0.993 & 0.988 \\
\hline
\end{tabular}

Note: Panel data, 16 OECD countries, $1990-98,125$ observations. ${ }^{\nabla}$ Indicates the parameters that are significant at a $15 \%$ probability threshold, $* 10 \%$ probability threshold, $* * 5 \%$ probability threshold and $* * * 1 \%$ probability threshold. 
Estimates of the static model with different depreciation rates

Table AII: Descriptive statistics for VC

\begin{tabular}{|c|c|c|c|c|c|}
\hline \multirow[t]{2}{*}{ Country } & \multirow[t]{2}{*}{ Period } & VC investment & $\begin{array}{l}\text { Venture capital stock } \\
\qquad \delta=30 \%\end{array}$ & $\begin{array}{l}\text { Venture capital stock } \\
\qquad \delta=45 \%\end{array}$ & $\begin{array}{l}\text { Venture capital stock } \\
\qquad \delta=60 \%\end{array}$ \\
\hline & & \multicolumn{4}{|c|}{ Growth rates } \\
\hline $\mathrm{AU}$ & $1995-98$ & -3.65 & -4.84 & -4.90 & -4.66 \\
\hline $\mathrm{BE}$ & $1990-97$ & 14.51 & 8.36 & 9.22 & 10.50 \\
\hline $\mathrm{CA}$ & 1995-98 & 34.50 & 40.72 & 40.31 & 39.36 \\
\hline DK & $1990-98$ & 14.96 & 9.59 & 10.67 & 11.79 \\
\hline FI & $1990-98$ & 24.63 & 27.92 & 27.33 & 26.74 \\
\hline FR & 1990-98 & 4.95 & 1.46 & 2.06 & 2.89 \\
\hline GE & $1990-98$ & 12.40 & 16.86 & 15.37 & 14.35 \\
\hline IR & 1990-97 & 1.20 & 5.59 & 4.48 & 3.64 \\
\hline IT & 1990-97 & 2.44 & 1.06 & 0.64 & 0.93 \\
\hline JP & 1994-98 & 8.46 & 13.55 & 13.34 & 12.39 \\
\hline NL & 1990-98 & 13.53 & 15.23 & 14.90 & 14.52 \\
\hline NO & $1990-97$ & 16.14 & 28.12 & 24.27 & 21.25 \\
\hline SP & 1990-98 & 13.91 & 10.86 & 11.49 & 12.14 \\
\hline SW & $1990-97$ & 4.81 & 13.20 & 13.69 & 13.22 \\
\hline UK & $1990-98$ & 5.96 & -0.82 & 0.76 & 2.41 \\
\hline US & $1990-98$ & 21.41 & 10.15 & 12.62 & 15.03 \\
\hline
\end{tabular}

Sources: OECD, MSTI, EVCA and own calculations 
Table AIII: Multifactor productivity estimation results in log-levels (with different depreciation rates of VC stock)

\begin{tabular}{|c|c|c|c|c|c|c|c|}
\hline \multicolumn{8}{|c|}{ Dependent variable Log MFP } \\
\hline & & \multicolumn{2}{|c|}{$\delta=30 \%$} & \multicolumn{2}{|c|}{$\delta=45 \%$} & \multicolumn{2}{|c|}{$\delta=60 \%$} \\
\hline \multicolumn{2}{|l|}{ Regressions (GLS) } & 1 & 2 & 3 & 4 & 5 & 6 \\
\hline \multirow[t]{2}{*}{ Log Venture capital stock (t-1) } & $L S V C$ & $0.013 * * *$ & $0.010^{* * *}$ & $0.012 * * *$ & $0.009 * * *$ & $0.011 * * *$ & $0.008 * * *$ \\
\hline & & $(5.24)$ & (3.15) & (4.98) & $(2.91)$ & $(4.59)$ & $(2.75)$ \\
\hline \multirow[t]{2}{*}{ Log Business R\&D capital stock (t-1) } & LSBRD & & $0.182 * * *$ & & $0.181 * * *$ & & $0.181 * * *$ \\
\hline & & & (9.10) & & $(9.14)$ & & $(9.24)$ \\
\hline \multirow[t]{2}{*}{ Log Public R\&D capital stock (t-2) } & LSPRD & & $0.092 *$ & & $0.101 * *$ & & $0.108^{* *}$ \\
\hline & & & (1.83) & & $(2.02)$ & & $(2.17)$ \\
\hline \multicolumn{8}{|l|}{ Control variables } \\
\hline \multirow[t]{2}{*}{ Employment rate growth $(\mathrm{t})$} & & $0.760 * * *$ & $0.618 * * *$ & $0.780 * * *$ & $0.625^{* * *}$ & $0.795 * * *$ & $0.624 * * *$ \\
\hline & & $(4.31)$ & $(3.71)$ & (4.33) & $(3.76)$ & $(4.30)$ & $(3.75)$ \\
\hline \multirow[t]{2}{*}{ German reunification dummy $(\mathrm{t})$} & & -0.004 & -0.014 & -0.005 & -0.015 & -0.007 & -0.016 \\
\hline & & $(-0.79)$ & $(-0.38)$ & $(-0.11)$ & $(-0.41)$ & $(-0.14)$ & $(-0.43)$ \\
\hline Country-specific intercept & & Yes & Yes & Yes & Yes & Yes & Yes \\
\hline Time dummies & & Yes & Yes & Yes & Yes & Yes & Yes \\
\hline Adjusted R-squared & & 0.941 & 0.961 & 0.939 & 0.962 & 0.937 & 0.963 \\
\hline
\end{tabular}

Note: Panel data, 16 countries, $1990-98,125$ observations. ${ }^{\nabla}$ Indicates the parameters that are significant at a $15 \%$ probability threshold, * $10 \%$ probability threshold, $* * 5 \%$ probability threshold and $* * * 1 \%$ probability threshold. 


\section{APPENDIX 2: Calculation of the variables}

\section{$\underline{\text { Business } R \& D \text { capital stocks, Public R\&D capital stocks }}$}

R\&D capital stocks are calculated following the perpetual inventory method. The stock at time $t$ is equal to the new investment at time $t$ plus the stock at time $t-1$ minus depreciation:

$S R_{t}=r_{t}+(1-\delta) S R_{t-1}$

$S R_{t}=r_{t}+(1-\delta) r_{t-1}+(1-\delta)^{2} r_{t-2}+(1-\delta)^{3} r_{t-3}+\ldots$

To construct the initial stock we assume a constant annual rate of growth of the past investments,

$$
\begin{aligned}
& S R_{t}=r_{t}+(1-\delta) \lambda r_{t}+(1-\delta)^{2} \lambda^{2} r_{t}+(1-\delta)^{3} \lambda^{3} r_{t}+\ldots \\
& S R_{t}=\frac{r_{t}}{1-\lambda(1-\delta)}
\end{aligned}
$$

where

$$
\begin{array}{ll}
S R_{t}= & \text { R\&D capital stock at time } t . \\
r_{t}= & \text { R\&D investment at time } t . \\
\delta \quad= & \text { Depreciation rate (constant over time). } \\
\lambda=\frac{1}{1+\eta} & \text { and } \quad \eta \quad \text { is the mean annual rate of growth of } r_{t} .
\end{array}
$$

The same formula has been used to calculate the Business R\&D Capital Stock (SBRD), the Public R\&D Capital Stock (SPRD).

\section{$\underline{\text { Venture capital stocks }}$}

$\mathrm{VC}$ stocks are calculated following the perpetual inventory method as for R\&D capital stocks.

$$
S V C_{t}=\frac{v c_{t}}{1-\lambda(1-\delta)}
$$

where

$$
\begin{array}{ll}
S V C_{t}= & \text { VC capital stock at time } t . \\
v c_{t}= & \text { VC investment at time } t . \\
\delta \quad= & \text { Depreciation rate (constant over time). } \\
\lambda=\frac{1}{1+\eta} & \text { and } \quad \eta \quad \text { is the mean annual rate of growth of } v c_{t} .
\end{array}
$$

In the following table, you will find the multiplicator $\lambda$ that we have calculated for each depreciation rate. 
Table AIV: Multiplicator with different depreciation rates of VC stock

\begin{tabular}{cccccc}
\hline \hline & & \multicolumn{4}{c}{$\lambda=1 /(1+\eta)$} \\
\cline { 3 - 5 } Country & Period & $\delta=15 \%$ & $30 \%$ & $45 \%$ & $60 \%$ \\
\hline AU & $1995-1998$ & 8.49 & 3.66 & 2.33 & 1.71 \\
BE & $1989-1998$ & 4.10 & 2.65 & 1.96 & 1.55 \\
CA & $1995-1998$ & 2.72 & 2.09 & 1.69 & 1.42 \\
DK & $1989-1998$ & 4.24 & 2.70 & 1.98 & 1.56 \\
FI & $1989-1998$ & 2.71 & 2.08 & 1.69 & 1.42 \\
FR & $1989-1998$ & 5.37 & 3.03 & 2.11 & 1.62 \\
GE & $1989-1998$ & 3.12 & 2.27 & 1.78 & 1.47 \\
IR & $1989-1998$ & 4.54 & 2.80 & 2.02 & 1.58 \\
IT & $1989-1998$ & 4.99 & 2.93 & 2.07 & 1.60 \\
JP & $1994-1998$ & 4.62 & 2.82 & 2.03 & 1.58 \\
NL & $1989-1998$ & 3.68 & 2.50 & 1.89 & 1.52 \\
NO & $1989-1998$ & 2.04 & 1.72 & 1.49 & 1.32 \\
SP & $1989-1998$ & 4.61 & 2.82 & 2.03 & 1.58 \\
SW & $1989-1998$ & 4.00 & 2.62 & 1.94 & 1.55 \\
UK & $1989-1998$ & 5.88 & 3.16 & 2.16 & 1.64 \\
US & $1989-1998$ & 4.24 & 2.70 & 1.98 & 1.56 \\
\hline \hline
\end{tabular}

Sources: Based on EVCA 